\title{
RELATIONS BETWEEN MAXIMAL ISOMETRIC STRENGTH AND COMPETITION PERFORMANCE AMONG YOUNG KAYAKERS
}

\author{
Nikola Toplica Stojanović, Zvezdan Savić, Miloš Paunović, Dragomir Dumbelović \\ Faculty of Sport and Physical Education, University of Nis, Serbia
}

\begin{abstract}
Introduction: The aim of this study is to determine if there are certain relations between maximal isometric strength and competition performance of young kayakers.

Methods: This study was conducted with a sample of 25 male young kayakers from the kayak clubs of Serbia and Macedonia, aged $11 \pm 1.5$ years. Kayakers were divided into two separate groups, group of pioneers aged 11,36 ( $\pm 1,54)$, and group of kadets aged 15( $\pm 1,58)$. Kayakers performed three isometric strength tests: hand grip, knee extensor, and lower back extensor. Testing was performed half an hour before the copmetition due to maximal performance, and more importantly test procedures did not have any negative effect on the final performance. Subjects were adviced to produce maximal effort as fast as they can. Correlation analysis was used to process obtained results in STATISTICA 8 for Windows.

Results: The overall analysis showed that there was a moderate correlation between all of maximal ismometric strength test results and competition performance among pioneer kayakers, and there was no statistical significant correlation between all of maximal ismometric strength test results and competition performance among kadet kayakers.

Discussion and Conclusion: The general objective of this study was to highlight the importance of maximal isometric force production as the contributor of competition performance. But this data should be considered with caution, because the paddeling techniques and anticipation during the race are often the most important parameters of success. However, strength developement should not be ignored while planning the training process.
\end{abstract}

Key words: kayaking, performance, force production.

\section{INTRODUCTION}

The physical development of children between the ages of 11 and 17 includes significant changes in the morphological characteristics and physical proportions in the body. It is a period when changes occur in the development of certain tissues (bones and muscles) and organs. This period, according to Kurelićet al. (1975), in a narrow sense represents the period of "adolescence" for girls it lasts from the ages of 10 to 11 , and from the ages of 15 to 16 , and for boys - from the ages of 12 to 13 , and from the ages of 17 to 18 . During this time, the first two years are known as puberty, a time which is characterized by a sudden in- crease in the longitudinal dimensions of the body; the following two years of puberty also see a continuation in this intense development and sexual maturation (Simić, Bunčić, and Ružić, 2015). The processes which determine physical development, as well as development during this time, are conditioned by relatively harmonized mutual effects of various endogenic and exogenic factors. Numerous studies indicate that muscle strain during these activities influences the development of the skeletal, muscle, cardiovascular, respiratory and other systems (Simićet al. 2015). Muscle strength can be defined as the maximum force or tension in the muscles or group of muscles which 
can be generated at a certain speed (Knuttgen and Kraemer, 1987). The positive effects of training with load among adult athletes are well-documented in literature (Chilibeck, Calder, and Sale, 1998; Sailors and Berg, 1987; Staron et al., 1994). Isometric strength training among adult males can result in an increase in strength of up to $92 \%$ and an increase in the muscle cross-section of up to $23 \%$ (Ikai and Fukunaga, 1970); dynamic exercises can increase strength by $30 \%$ (Moritani and DeVries, 1980). Both types of training are also effective in increasing strength among children and adolescents prior to puberty (Rowland, 2005; Tolfrey, 2007). However, Mersh, and Stoboy (1989) reported significantly increased muscle size after 10 weeks of isometric training among prepubescent boys. In addition, Fukunaga, Funato, and Ikegawa (1992) monitored the progress of 50 boys and girls aged 6.9 to 10.9 during a 12 -week training program, which resulted in significant improvements in the cross-section of their muscles (mCSA). These findings indicate that even though muscle hypertrophy can set in, other factors, in addition to the changes in the cross-section of the muscle, mostly lead to an increase in strength during or prior to early puberty (Tolfrey, 2007; Zatsiorsky and Kreamer, 2009). Numerous studies, following programmed isometric training, noted an increase in body volume, which is related to muscle hypertrophy (Kenehisa and Miyahita, 1983; Kitai and Sale, 1989; Schott, McCully, and Rutherford, 1995). However, a consequence of isometric training for the increase in muscle strength does not only lead to an increase in body volume, but also to neurological adaptation. An increase in the value of maximum isometric force occurs during training with maximum isometric contractions, but also with submaximum muscle contractions (Hettinger and Muller, 1953; A1ways, Sale, and MacDougall, 1990; Davies et al., 1988; Daveis and Young, 1983; Kubo et al., 2001; Lyle and Rutherford, 1998; Macalu- soet al., 2000). Training with maximum isometric muscle contractions is primarily used when working with healthy individuals and athletes (Fleck and Kramer, 2004). Most of the studies which have surveyed the effects of isometric training on the development of muscle force relied on maximum voluntary muscle contractions which lasted for a period of 3-10 s (Schott, McCully, and Rutherford, 1995; Lyle and Rutherford, 1998). The optimum increase in the development of muscle force can occur during a small number of isometric muscle contractions of an extended duration, but also a large number of isometric muscle contractions of a short duration, with almost identical progress (Davies and Young, 1983). Another factor, which can exert influence during isometric training, is the speed needed to achieve maximum muscle force. This claim can be substantiated by the research of other authors Maffiuletti and Martin (2001), who applied a seven-week isometric training program among a group of participants who achieved maximum isometric force as quickly as possible (in approximately 1s) when compared to a group which needed $4 \mathrm{~s}$ to reach maximum isometric force (28\% vs 16\%).

\section{Aim and objectives of the study}

The aim of this study is to determine to which extent the maximum force of the leg and back extensors and the hand grip influence success at competitions. Furthermore, it is important to determine the extent of the effect of each person individually, so that we could approach as adequately as possible the modification of the training process with the aim of achieving good ranking at competitions in the future.

\section{METHOD}

\section{Description of the research}

Kayakers were tested at an international competition held in Nis in 2017, for the pioneer and cadet age categories. The competitors were tested in the facilities of the kayak-canoe club "Gusar", after the competition. It is im- 
portant to mention that each of the participants had at their disposal 30 minutes of rest after the end of the competition for full recovery. Prior to the beginning of the testing, each participant was subjected to a progressive warmup for a period of 10 minutes. The first part of the warm-up ( $5 \mathrm{~min}$ ) was focused on increasing work ability and heart rate (low intensity skipping). The second part of the warm-up (5 min) included exercises for the activation of large muscle groups (squats, lunges forward and to the side, push-ups, etc.), as well as exercises for the increase of mobility in the joints (hyperextensions, twists, forward bends, rotations of the shoulders and hips). All of the exercises in the second part of the warm-up were performed with speed, volume and intensity controlled by the invigilator to achieve a more complete warm-up, which at the same time would not lead to fatigue. The measuring instruments (handgrip dynamometry, dynamometry of the leg extensors and dynamometry of the back extensors) were located along the rest stops so as not to disrupt the participants when performing the tests. Next to every measuring instrument there was one invigilator and one demonstrator who showed (demonstrated) the participants how to perform the task. After the demonstration, when the invigilator gave the sign, the participant performed the exercise with maximum intensity. If the participant were to perform the test incorrectly, they had to redo it successfully. The pause between two individual attempts and between the tests was at least 90 seconds, so as to exclude the possibility of fatigue affecting the outcome of the results. All of the participants were tested in the same order on the measuring instruments so as to avoid any imprecision during measuring and any errors in completing the protocol.

\section{The sample of participants}

The sample of participants in this research consisted of the participants from three clubs from Serbia and five clubs from Macedonia. The clubs from Serbia consisted of the kayak-canoe club "Gusar", the kayak-canoe club "Medicinar" from Nis and the kayak club "Ibar" from Kraljevo. The clubs from Macedonia included the kayak club "Ilinden 90" from Skopje, the kayak club "Vardar", "Babuna", "Gemigi 903" and "Vila Zora" from Veles. All of the kayakers competed in the discipline K-1 slalom, in the men's category. This research included 25 young kayakers. The kayakers were divided according to the criterion of their competitive category into a group of pioneers $11,36( \pm 1,54$ years $)$ and cadets $15( \pm 1,58$ years $)$. The group of pioneers $\mathrm{TB}=150,7( \pm 11,98 \mathrm{~cm}) ; \mathrm{TM}=48,94 \quad( \pm 12,27$ $\mathrm{kg})$ numbered 16, and the group of cadets $\mathrm{TB}=171( \pm 7,21 \mathrm{~cm}) ; \mathrm{TM}=66,60( \pm 7,94 \mathrm{~kg})$ included 9 participants. The research was carried out in accordance with the ethical standards of the World Medical Association Declaration of Helsinki of 1964, modified in 2013. The participants were familiar with the basic methods and aims of the experiment. In order to realize the research, we obtained the agreement from the kayak clubs and the participants who took part in the realization of the testing.

A description of the measuring instruments

\section{Dynamometry of the back extensors}

An electric dynamometer (probe - force generator) was constructed in the TechnicalDevelopmental Center in Novi Sad, type $\mathrm{DSS} / 500$, serial number 98001, maximum weight $500 \mathrm{~kg}$ and load produced $2,2 \mathrm{mVN}$. The principle according to which this force generator (the probe) operates is based on piezoelectric effect. The electrical current has a constant voltage when flowing through the semi-conductor. The generated force which is produced by the participants in generator force, by sliding hooks during the measuring in opposite directions within the probe, leads to metal plates on the special semi-conductors applying pressure. The produced electrical energy is processed via the "AD" convertor, and is recorded on the monitor of the hardware- 
software system in kilograms with decimals. This measuring instrument is used to measure the intensity of the isometric and ballistic muscle potential. The software which is used for the purpose of analyzing the dynamogram is "Force Static".

The task: The participant stands straight, hands on his thighs, an in his hands there is force generator with a probe attached to it; at the signal from the invigilator the participant at the same time, with both hands, pulls the force generator with maximum speed backwards and upwards.

\section{Dynamometry of the leg extensors}

The same instrument is used as in the dynamometry of the leg extensors.

The task: The participants stands with his legs slightly flexed, his hands behind his back, at the level of the gluteus, with both hands on the force generator attached to the probe, and tries as hard as possible to extend his legs while keeping his back straight.

\section{Dynamometry of the hand grip}

The same instrument is used as in the dynamometry of the leg and back extensors.

The task: The participant stands upright, hands next to his body and with the dominant hand at the signal from the invigilator squeezes as hard as possible the metal instrument to which the probe is attached. The probe gives results in Newtons.

\section{RESULTS}

The values of the central and dispersion parameters, the skewness and kurtosis of the variables of handgrip dynamometry, dynamometry of the leg and back extensors indicate the possibility of applying parametric procedures (table 1 and 2).

Table 1. Descriptive statistics (pioneers)

\begin{tabular}{llcccccccc}
\hline Variable & N & Mean & Min. & Max. & Range & Std. Dev. & Skew. & Kurt. & K-S \\
\hline DINSA & 16 & 194,94 & 80 & 350 & 270 & 75,10 & 0,38 & $-0,29$ & 0.10 \\
DINON & 16 & 643,88 & 258 & 1026 & 768 & 226,25 & 0,17 & $-0,83$ & 0.14 \\
DINOL & 16 & 695,00 & 226 & 1146 & 920 & 265,18 & 0,29 & $-0,60$ & 0.21 \\
\hline
\end{tabular}

Legend: N - number of participants; Mean - arithmetic means; Std.Dev. - standard deviation; Min. - minimum results; Max. - maximum results; Range - range of the results; Skew. - symmetric distribution of the results; Kurt. - flat distribution of the results; K-S - Kolmogorov-Smirnovtest of distribution normalcy.

Table 2. Descriptive statistics (cadets)

\begin{tabular}{llcccccccc}
\hline Variable & N & Mean & Min. & Max. & Range & Std. Dev. & Skew. & Kurt. & K-S \\
\hline DINŠA & 9 & 379 & 320 & 440 & 120 & 39,83 & 0,18 & $-1,21$ & 0.23 \\
DINON & 9 & 1103 & 779 & 1434 & 655 & 207,65 & $-0,11$ & $-0,38$ & 0.13 \\
DINOL & 9 & 1089 & 822 & 1346 & 524 & 171,94 & $-0,11$ & $-1,00$ & 0.16 \\
\hline
\end{tabular}

Legend: N - number of participants; Mean - arithmetic means; Std.Dev. - standard deviation; Min. - minimum results; Max. - maximum results; Range - range of the results; Skew. - symmetric distribution of the results; Kurt. - flat distribution of the results; K-S - Kolmogorov-Smirnov test of distribution normalcy.

The table shows the minimum (Min.) and maximum (Max.) values of the variables of handgrip dynamometry, and dynamometry of the leg and back extensors. The values of skewness indicate that the distribution of all these variables is symmetrical. That is, the curve of the distribution of the results is within the limits of normality, and most of the results are grouped around the means. The lower values for kurtosis indicate that for all the vari- 
ables of the participants kurtosis ranges within the values of the platykurtic curve. The values of the Kolmogorov-Smirnov test indicate that the distribution of the results ranges within the normal values. The relationship between the values of standard deviation and average values indicate the decreased discrimination of all the variables. The results of the relation between the range and standard deviations, which are increased, also indicate the decreased discriminant nature of the results. The approximate range of all the variables does not consist of more than 3 standard deviations, which is significantly less than 6 . This shows how many standard deviations should be included in the range of the results for the test to have an adequate discriminant value.

Table 3. Correlation matrix (pioneers)

\begin{tabular}{|c|c|c|c|c|}
\hline & DINŠA & DINON & DINOL & PLAS \\
\hline$\overline{\text { DINŠA }}$ & & 0,86 & 0,90 & $-0,50$ \\
\hline DINON & & & 0,89 & $-0,57$ \\
\hline DINOL & & & & $-0,55$ \\
\hline PLAS & & & & \\
\hline
\end{tabular}

Legend: DINŠA - handgrip dynamometry; DINON - dynamometry of the leg extensors; DINLON - dynamometry of the back extensors; PLAS - rank at competition; P-level $\mathrm{p}<0.05 ; \mathrm{r}$ - Pearson correlation coefficient

On the base of the results shown in table 3 we can conclude that among the variables of the studied space of maximum isometric strength (DINŠA, DINON and DINOL) and rank at competition there is a moderate, statistically significant correlation $(r=-.50 ; r=-.57 ; r=-.55)$. We can also conclude that there is a statistically significant high correlation between the variables DINŠA and DINON $(r=.86)$, DINŠA and DINOL $(r=.90)$ and DINON and DINOL $(\mathrm{r}=.89)$.

Table 4. Correlation matrix (cadets)

\begin{tabular}{lcccc}
\hline & DINŠA & DINON & DINOL & PLAS \\
\hline DINŠA & 0,23 & $-0,05$ & 0,19 \\
DINON & & $\mathbf{0 , 7 1}$ & 0,20 \\
DINOL & & & 0,27 \\
PLAS & & & \\
\hline
\end{tabular}

\footnotetext{
Legend: DINŠA - handgrip dynamometry; DINON - dynamometry of the leg extensors; DINLON - dynamometry of the back extensors; PLAS - rank at competition; P-level $\mathrm{p}<0.05 ; \mathrm{r}$ - Pearson correlation coefficient
}

On the base of the results shown in table 4 we can conclude that among the variables of the studied space of maximum isometric strength (DINŠA, DINON and DINOL) and rank at competition there is a relatively low correlation $(\mathrm{r}=.19 ; \mathrm{r}=.20 ; \mathrm{r}=.27)$. In addition, we can conclude that there is a statistically significant mid-high correlation between the variables DINON and DINOL $(\mathrm{r}=.71)$.

\section{DISCUSSION AND CONCLUSION}

A hand is the basic manipulative organ and implement of people, while the muscle force of the finger flexors, that is, the force of the handgrip is identified as the limiting factor of all the manipulative activities realized by the cranial part of the body (Tyldesley and Grieve, 1996). Studies on the hand-grip are widely dispersed considering that the force of the handgrip (and the muscles which take 
part in the grip) mutually affects the other muscle groups, including the lower extremities. It is a good all-encompassing measure for a reliable and valid evaluation of the overall strength of the body (Bohannon, 2001). With the help of certain motor abilities, including the maximum force of the handgrip, we can determine the level of general physical fitness as one of the important indicators and factors on which sports success and top sports results depend. Therefore, we can claim with certainty that data and information obtained measuring these abilities play an important role in the programming and planning of the training process, selection and prognostic criteria (Bohannon, 2001). In the research carried out by Jevtićet al. (2015) the authors studied differences in isometric endurance of the lumbar extensors among preadolescents and confirmed that there are significant differences between the age categories of children aged 11 to 14 $(p<0.05)$. On the base of the results it could be said that muscle endurance significantly increases from the ages of 11 to 13 . Such a trend can be a consequence of the sudden growth and development and we can characterize it as a critical period for the occurrence of postural deformity (Viry, Creveuil, and Marcelli, 1999) and the lumbar syndrome (Johnson et al., 2009). Since the characteristics of growth and development are significantly connected to the isometric endurance of the lumbar extensors and the abdominal musculature among children aged 7 to 14 , we might say that the increase in body weight and body height influences the increase in the isometric force of the lumbar extensors (Dejanović and Živković, 2008). The differences which occurred in the maximum isometric muscle force between children aged 11 to 14 can be related to the differences which occur in individual motor skills and in general the age characteristics of children. Thus, with most of the motor skills there are differences in the age and trend of improvement (Badrićet al., 2012). The pre- vious conclusion unambiguously indicates the fact that the maximum force of the hand flexors and extensors of the back and legs has a considerable effect on the success at competitions among younger competitive categories (pioneers), which is also confirmed by the results of our study. On the other hand, in the case of the cadets there is no significant connection between the aforementioned parameters and success at competitions. This might be explained by a decrease in the trend of development of the motor skills after the age of 14, especially the isometric force of the lumbar extensors (Badrićet al., 2012). The influence of these abilities is secondary, which further indicates that success at competitions of a higher quality is determined by many other factors. Unfortunately, this research did not include all the segments which might significantly influence the general ranking.

Numerous authors (Babiak, 1998, 2004; BabiakandDoder, 2005, 2006) point out the fact that if the force of the flexors of the fingers and hand can be taken as a measuring unit, then each athlete should have equal force in his other hand, but also force of the abdominal press close to these values. The force of the back musculature should be more than 2,5 times greater, while the force of the leg extensors almost 6 times greater than the measuring unit. This relationship can be defined as a harmonious canon of force. The results of this study confirm this claim. One of the reasons explaining the obtained results can be the difference in the age of the participants (from 11 to 25). Therefore, we could not accept the conclusion that the denominator between the dynamometry of the leg extensors and handgrip is 6,5 and this information should not be taken at face value. The research of these authors is similar to ours because of the assumption that if the values of the dynamometric force of the kayakers are interpreted as the predictor measure of success at competitions, then this problem also offers the basis for reaching conclu- 
sions on the joint effects of the muscle forces and the relationship of those muscle groups which are directly included in the training of kayakers, compared to those which are not. A certain advantage of the research of the aforementioned authors is precisely the fact that a significantly wider range of measures of dynamometric force of the kayakers was used to analyze the relationship between the forces of these athletes. On that base we could conclude whether the training process should focus on a one-sided or complex approach (Babiak, 2004).

When we compare the results of our research with those obtained by Cuk (2016) on a sample of Slovenian judokas aged 13 to 16 , it is clear that the results of the judokas, compared to the kayakers included in our study, unambiguously are of higher values for almost all the parameters, with the exception of similar results for the minimum strength of the handgrip (judokas 300N, kayakers 320N). On the base of the research carried out by Kuburovic (2015) which included a sample of 54 male participants, aged between 16 and 17, members of a handball school in Backa Palan$\mathrm{ka}$, we can conclude that the handball players achieved better results for the parameters of dynamometry of the back extensors and handgrip, except for the minimum values (DINŠA $270 \mathrm{~N}$, opposed to $320 \mathrm{~N}$ among kayakers and DINOL $697 \mathrm{~N}$, and for the kayakers $822 \mathrm{~N}$ ). An explanation for these better results in favor of the handball players could be could be the age of the participants. Of course, it is important to mention that specificities, just like the training process involved in the aforementioned sports, differ significantly. However, this does not diminish the importance of the maximum isometric force as a very important ability in the prediction of sports success. The question is whether younger kayakers' back strength is more dominant than leg strength, and whether leg strength plays any role in the final outcome. Another issue is whether it is necessary to view the length of the training period (the training experience) of the young kayakers as a very important component for success at competitions. This research certainly opens the possibility for other researchers to view this problem from various aspects and more adequately, since kayaking is a very specific and multicomponent sport. On the base of the obtained results, coaches can determine whether younger age categories should pay attention solely to the development of the rowing technique or should at the same time work on improving the quality of strength during the training process.

\section{REFERENCES}

Always, SE., Sale, DG., and MacDougall, JD. (1990), Twich contractile adaption are not depedent on the intensity of isometric exercise in the human triceps surae, Eur J Appl Physiol vol. 60 , pp. 346-52.

Babiak, J. (1998), (Dis)harmonija sile i trening rukometaša, U VI Međunarodno savetovanje Novosadski maraton, "Dijetetski proizvodi i trenažni proces ", Novi Sad: Novosadski maraton, pp. 59-62.

Babiak, J. (2004), Harmonijski kanon sile i trening sportista. Aktuelno u praksi, vol. 16, pp. 16-24.

Babiak, J., and Doder, D. (2005), Harmonijski kanon sile u borilačkim sportovima, U I Međunarodni simpoziju "Efekti $i$ uticaji različitih modela trenažnog procesa na antropološki status sportista u borilačkim sportovima “, Pančevo: Sportski savez opštine Pančevo, pp. 6-10

Babiak, J., and Doder, D. (2006), Harmonijski kanon sile i univerzalni modelšampiona u karate borbama, U II Međunarodni simpoziju "Modeli trenažnog

procesa u borilačkim sportovima" , Pančevo: Sportski savez opštine, pp. 6-11.

Badrić, M., Sporiš, G., Trklja, E., and Petrović, J. (2012), Trend razvoja motoričkih sposobnosti učenika od 5. do 8. razreda, $U$ 
Zbornik radova Findak, $V$. (ur.) 21. ljetne škole kineziologa Republike Hrvatske Programiranje rada u području edukacije, sporta, sportske rekreacije i kineziterapije, Zagreb, Hrvatski kineziološki savez, pp. 115-121.

Bohannon, R. W. (2001). Dynamometer measurements of hand grip strength predict multiple outcomes, Percept Motor Skills, vol. 93, pp. 323-328.

Chilibeck, P., Calder A., and Sale, D. (1998), A comparison of strength and muscle mass increases during resistance training in young women, European Journal of Applied Physiology and Occupational Physiology, vol. 77, pp. 170-175.

Цук, Ш. (2016), Моторички потенщијал и телесна композиција младих иудиста Словеније, Докторска дисертација, Ниш: Факултет спорта и физичког васпитања

Davies, CTM., and Young, K.(1983), Effects of training at 30 and $100 \%$ maximal isometric force on the contractile properties of the triceps surae of man, J Physiol, vol. 36, pp. 22-3.

Davies, BN., Parker, DF., Rutheford, OM., and Jones, DA. (1988), Changes in strength and cross sectional area of the elbow flexors as a result of isometric strength training, Eur $J$ Appl Physio, vol. 57, pp. 667-670.

Dejanović, A., and Živković, D. (2008), The connection between the anthropometric characteristics of the body and the isometric endurance of the lumbar and abdominal musculature of the children, Facta Universitatis, Series: Physical Education and Sport, vol. 6, no. 2, pp. 85-93.

Fleck. SJ., and Kramer, WJ. (2004), Designing resistance training programs (3nd edition), Champaign, IL: Human Kinetitcs.

Fukunaga T., Funato K, and Ikegawa S. (1992), The effects of resistance training on muscle area and strength in prepubertal age, Annals of Physiology and Anthropology, vol. 11, pp. 357-364.

Hettinger, R., and Muller, E.(1953), Mus- kelleistung und Muskeltraining, Arbeits Physiology, vol. 15, pp. 111-126.

Ikai M., and Fukunaga T. (1970), A study on training effect on strength per unit crosssectional area of muscle by means of Ultrasonic measurement, Intern $Z$ Angew Physiologica, vol. 28, pp. 173-180.

Jevtić, N., Marinković, D., Javorac, D., Semeredi, S., and Obradović, S. (2015), Ima li razlike u izometrijskoj izdržljivosti lumbalnih ekstenzora kod predadolescenata, Novi Sad: Fakultet sporta i fizičkog vaspitanja.

Johnson, O.E., Mbada, C.E., Akosile, C.O., and Agbeja, O.A., (2009), Isometric endurance of the back extensors in school-aged adolescents with and without low back pain, Journal of Back and Musculoskeletal Rehabilitation, vol. 22, no. (4), pp. 205- 211.

Kenehisa, PH., and Miyahita, M. (1983), Effect of isometric and isokinetic muscle training on static strength and dynamic power, Eur J Appl Physiol, vol. 50, pp. 365-371.

Kitai, TA., and Sale, DG. (1989), Specificity of joint angle in isometric training, Eur $J$ Appl Physiol Occup Physiol, vol. 58, no. 7, 744-748

Knuttgen, H., and Kraemer W. (1987), Terminology and measurements in exercise performance, Journal of Applied Sports Science Research, vol. 1, pp. 1-10.

Kubo, K., Kenehisa, H., Ito, M., and Fukanga, T. (2001), Effects of isometric training on elastic of human tendon structures in vivo, J Appl Physiol, vol. 91, pp. 26-32.

Кубуровић, Д. (2015), Утицај миогених способности и нивоа технике на дужину једноручног бачања лопти различитих тежина код младих рукометаша, Докторска дисертација, Сремска Каменица, Факултет за спорт и туризам.

Kurelić, N., Momirović, K., Stojanović, M., Šturm, J., Radojević, Đ., Viskić-Štalec, N. (1975) Struktura i razvoj morfoloških i motoričkih dimenzija omladine. Beograd: Fakultet za fizičku kulturu. 
Lyle, N., and Rutherford, OM. (1998), A comparasion of voluntary versus stimulated strength training of the human abductors policies muscle, J Sports Sci, vol. 16, pp. 267-270.

Macaluso, A., De Vitto. G., Felici, F., and Nimmo, MA. (2000), Electromyogram changes during sustained contaction after resistance training in women in their 3 rd and 8th decades, Eur J Appl Physiol, vol. 82, 418-424.

Maffiuletti, NA., and Martin, A. (2001), Progressive versus rapid rate of contaction during $7 \mathrm{wk}$ of isometric resistance training, Med Sci Sport Exerc, vol. 33, 1220-1227.

Mersh, F., and Stoboy, H. (1989), Strength training and muscle hypertrophy in children. In Oseid S, Carlsen K., (Eds.), Children and Exercise XIII, Human Kinetics, Champaign, pp. 165-182.

Moritani, T., and DeVries, H. (1980), Potential for gross hypertrophy in older man, Journal of Gerontology, vol. 35, pp. 672682.

Rowland, T. (2005), Children's Exercise Physiology, Human Kinetics, Champaign.

Sailors M, and Berg, K. (1987), Comparison of responses to weight training in pubescent boys and men, Journal of Sports Medicine, vol. 27, pp. 30-37.

Schott, J., McCully, K., and Rutheford, OM. (1995), The role of metabolites in strength training. Short versus long isometric contractions, Eur J Appl Physiol Occup Physiol, vol.
71, no. 4, pp.337-341.

Staron, R., Karapondo, D., Kraemer, W., Fry, A., Gordon, S., Falkel, J., Hagerman, F., and Hikida, R. (1994), Skeletal Muscle Adaptations During Early Phase of Heavy Resistance Training in Men and Women, Journal of Applied Physiology, vol. 76, 1247-1255.

Tolfrey, K. (2007), Responses to training, In Armstrong N. (ed), Paediatric exercise science: Advances in sport and exercise ecience series, Churchill Livingstone, pp. 213234.

Tyldesley, B., Grieve, J. (1996). Muscles, nerves and movement: Kinesiology in daily living (Sec. Ed.), Blackwell Science LTD, Oxford OX2 oEL, England, Edinburgh.

Simić, D., Bunčić, V., and Ružić, S. (2015), Kanoničke relacije morfoloških karakteristika i motoričkih sposobnosti mladih košarkaša, In Jovanović, M., and Nićin, Đ., Treća međunarodna konferencija, 'Sportske nauke $i$ zdravlje“, Zbornik Radova, Banja Luka, 15. 3. 2013, Panevropski Univerzitet „Apeiron“, Banja Luka, pp.

Viry, P., Creveuil, C., and Marcelli, C, (1999), Nonspecific back pain in children. A search for associated factors in 14-year-old schoolchildren, Revue du Rhumatisme English Edition, vol. 66, pp. 382-388.

Zatsiorsky, V.M., and Kraemer, W. J. (2009), Nauka i praksa u treningu snage, DataStatus, Beograd.

Correspondence:

Nikola Toplica Stojanović Faculty of Sport and Physical Education, University of Nis Čarnojevića 10a Niš 18000, Serbia E-mail: nikola987_nish@hotmail.com 